\title{
Karakter Morfologi dan Identifikasi Hama pada Tanaman Dalugha (Cyrtosperma merkusii (Hassk.) Schott) di Kabupaten Kepulauan Talaud Propinsi Sulawesi Utara
}

\author{
Paulus L. Leu ${ }^{1)}$, Orbanus Naharia ${ }^{1)}$, Emma Mauren Moko²), \\ Aser Yalindua $^{2}$, Jantje Ngangi ${ }^{* *}$ \\ 1) Program Studi Biologi Program Pascasarjana Universitas Negeri Manado, Indonesia \\ 2) Program Studi Biologi Universitas Negeri Manado, Indonesia \\ ${ }^{*}$ Corresponding author: jantjengangi@unima.ac.id
}

\begin{abstract}
ABSTRAK
Tanaman dalugha (Cyrtosperma merkusii (Hassk.) Schott) merupakan tanaman endemik di Propinsi Sulawesi Utara yang perlu dilindungi dari serangan organisme pengganggu tumbuhan. Karakter morfologi dan Identifikasi hama sangat perlu untuk kajian ilmiah tentang budidaya tanaman endemik dalugha sebagai sumber pangan lokal di Sulawesi Utara. Penelitian ini bertujuan untuk mengetahui karakter morfologi dan identifikasi hama pada tanaman dalugha. Lokasi penelitian di desa Moronge, Kecamatan Moronge, Kabupaten Kepulauan Talaud. Penelitian ini menggunakan metode deskriptif kualitatif, pengambilan sampel hama ditentukan dengan teknik purposive sampling. Karakter morfologi dan identifikasi hama dilakukan dengan menggunakan buku kunci determinasi serangga hama dan aplikasi google lens dengan tingkat akurasi pengenalan spesies hewan yang tepat. Hasil penelitian menunjukkan bahwa adanya keragaman hama pada tanaman dalugha yang terbagi dalam tiga kelas: Kelas Gastropoda yaitu Bekicot (Achatina fulica), Keong semak (Bradybaena similaris), Siput hijau (Rhinocochlis nasuta), Siput pita (Caracolus marginella), Siput kebun (Cornu aspersum), dan Sumpil (Subulina octona); Kelas Insekta yaitu Belalang hijau (Oxya servile), Jangkrik semak (Tettigonia caudate), Kumbang daun (Asphaera lustrans), Kepik kaki daun tumbuhan (Leptoglossus australis), Kutu kebul (Bemisia tabaci), Semut kebun hitam (Lasius niger), Ulat tanduk talas (Theretra oldenlandiae), Kecoa (Periplaneta americana L.), dan Kecoa surinam (Pycnoscelus surinamensis); serta Kelas Oligochaeta yaitu Cacing tanah (Lumbricus rubellus).
\end{abstract}

Kata kunci: dalugha; hama; identifikasi; morfologi; Sulawesi Utara

\section{Morphological Characteristics and Pest Identification on Dalugha Plants (Cyrtosperma merkusii (Hassk.) Schott) in Talaud Islands District, North Sulawesi Province}

\begin{abstract}
Dalugha plants (Cyrtosperma merkusii (Hassk.) Schott) are endemic plants in North Sulawesi Province which need to be protected from attack by plant-disturbing organisms. Morphological characters and identification of pests are very necessary for scientific studies on the cultivation of endemic plants of dalugha as a local food source in North Sulawesi. This study aims to determine the morphological characters and identification of pests in dalugha plants. The research location is in Moronge Village, Moronge District, Talaud Islands Regency. This study used a qualitative descriptive method, the sampling of pests was determined by purposive sampling technique. Morphological characters and identification of pests were carried out using the key book for insect pest determination and the Google Lens application with an accurate level of recognition of animal species. The results showed that there was a diversity of pests in Dalugha plants which were divided into three classes: Gastropod class namely Bekicot (Achatina fulica), Keong semak (Bradybaena similaris), Siput hijau (Rhinocochlis nasuta), Siput pita (Caracolus marginella), Siput kebun (Cornu aspersum), and Sumpil (Subulina octona); Class Insects are Belalang hijau (Oxya servile), Jangkrik semak (Tettigonia caudate), Kumbang daun (Asphaera lustrans), Kepik kaki daun tumbuhan (Leptoglossus australis), Kutu kebul (Bemisia tabaci), Semut kebun hitam (Lasius
\end{abstract}


niger), Ulat tanduk (Theretra oldenlandiae), Kecoa (Periplaneta americana L.), and Kecoa surinam (Pycnoscelus surinamensis) and Oligochaeta class namely Cacing tanah (Lumbricus rubellus).

Keywords: dalugha; identification; morphology; North Sulawesi; pest

(Article History：Received 24-02-2021; Accepted 26-04-2021; Published 30-04-2021)

\section{PENDAHULUAN}

Perlindungan tanaman untuk mengurangi organisme pengganggu tumbuhan harus menjadi perhatian dan tanggung jawab masyarakat setempat dan Pemerintah. Tanaman dalugha (Cyrtosperma merkusii (Hassk.) Schott) merupakan tanaman endemik di Provinsi Sulawesi Utara yang perlu dilindungi dari serangan berbagai organisme pengganggu tumbuhan. Salah satu organisme pengganggu tumbuhan menurut Sumarna (2018) adalah hama yakni makhluk hidup atau organisme yang dapat mengganggu pertumbuhan dan perkembangan tanaman.

Ratnadass et al. (2012) menyatakan bahwa para petani menghadapi masalah perlindungan tanaman di daerah beriklim tropis dengan adanya serangan berbagai hama berupa tungau, serangga, nematoda dan myriapoda. Faktor alam seperti suhu dan kelembaban juga akan secara langsung mempengaruhi perkembangan dan kelangsungan hidup patogen, hama, musuh alami, pesaing dan vektor (Tubby \& Webber, 2010). Katsaruware-Chapoto et al. (2017) menyata-kan bahwa faktor alam dan antropogenik menyebabkan perubahan kondisi lingkungan yang mempengaruhi perubahan kelimpahan dan keanekaragaman hama serangga. Sutoyo (2010) mengemukakan bahwa varietas asli atau tradisional lebih tahan pada penyakit dan serangga lokal, maka untuk mengurangi kerusakan pada tanaman dan memaksimalkan produktivitas pertanian, perlu adanya deteksi hama dan penyakit tanaman. Tanaman dalugha sangat perlu mendapat perlindungan karena berpotensi sebagai sumber pangan lokal alternatif di Sulawesi Utara (Lintang et al., 2016). Bahkan Ratag et al. (2018) berpendapat bahwa tanaman dalugha adalah satu-satunya spesies dalam genus Cyrtosperma yang dapat dimakan, baik umbi maupun daun.

Berbagai kajian ilmiah tentang tanaman dalugha telah dilakukan namun masih terbatas termasuk karakter morfologi dan identifikasi hama pada tanaman dalugha di Kepulauan
Talaud Provinsi Sulawesi Utara. Data tentang morfologi dan identifikasi hama pada tanaman dalugha sangat penting untuk memahami akan adanya hama dan dampak kerusakan berbagai hama pada tanaman dalugha. Serangan hama yang sering ditemukan pada tanaman dalugha menurut masyarakat setempat adalah serangan hama siput. Rao (2011) dalam tulisannya mengutip temuan hama pada talas rawa raksasa dari beberapa sumber di mana adanya hama pada tanaman dalugha antara lain: Mealy bugs Pseudococcus, Nr.adonium L., Ferrisiana virgata Ck11, Bag worm, Hippotion sp., Spodoptera litura, dan Theretra pinastrina memakan daun talas rawa raksasa. Kay (1987) melaporkan adanya hama kumbang talas (Papuana huebneri) pada umbi dan Aphis gossypii yang dapat menularkan penyakit virus pada talas rawa raksasa serta hama tikus yang menyebabkan kerugian besar di beberapa pulau.

Oleh karena itu, masyarakat lokal harus mampu mengambil keputusan dan tindakan yang tepat menanggulangi serangan organisme penggangu tumbuhan agar dampak serangan tidak meluas pada tanaman lainnya secara khusus tanaman dalugha. Upaya perlindungan tanaman ini akan meningkatkan ketahanan dalugha untuk tetap hidup dan berkembang serta memaksimalkan produktivitas tanaman dalugha sebagai sumber pangan lokal yang bernilai dan bermanfaat bagi masyarakat lokal khususnya dan masyarakat luas pada umumnya. Penelitian ini bertujuan untuk mengetahui karakter morfologi dan identifikasi hama pada tanaman dalugha.

\section{METODE PENELITIAN}

Penelitian ini menggunakan metode penelitian deskriptif kualitatif (Raco, 2010; Suyitno, 2018). Identifikasi hama pada tanaman dalugha ditentukan dengan teknik purposive sampling (Sugiyono, 2016).

\section{Survei Lahan \\ Penelitian dimulai dengan menghubungi Pemerintah Kabupaten}


Kepulauan Talaud, Kecamatan Moronge, Desa Moronge untuk mendapatkan data lokasi bertumbuhnya tanaman dalugha di Kabupaten Kepulauan Talaud. Pemilihan lokasi sampling secara purposive sampling yaitu Desa Moronge, pengambilan sampel diambil pada beberapa titik tempat tumbuhnya tanaman dalugha yang dianggap cukup mewakili populasi sampel dalugha yang dapat teridentifikasi berbagai jenis hama.

\section{Pengambilan Sampel Jenis-Jenis Hama Tanaman Dalugha}

Identifikasi jenis-jenis hama dilakukan dengan mengamati secara langsung jenis-jenis hama pada tanaman dalugha, selanjutnya mengambil foto atau mendokumentasikan jenis-jenis hama yang ditemukan serta mencatat hasil pengamatan yang terdapat di lahan tersebut.

\section{Waktu dan Tempat Penelitian}

Penelitian ini dilaksanakan di Desa Moronge Kecamatan Moronge Kabupaten Kepulauan Talaud pada bulan Februari 2020. Desa Moronge secara administratif berada di Kecamatan Moronge, Kabupaten Kepulauan Talaud dengan letak geografis $3^{\circ} 54^{\prime} 26.44^{\prime \prime}$ Lintang Utara-126 $42^{\circ} 1.44^{\prime \prime}$ Bujur Timur dan berada pada ketinggian 47 meter dari permukaan laut (dpl). Desa Moronge dapat dilihat pada Gambar 1.

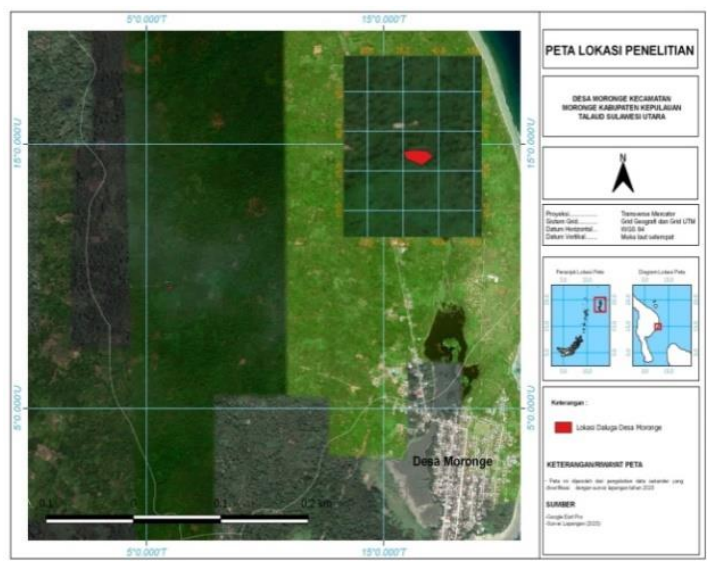

Gambar 1. Peta Desa Moronge (Google Earth Pro, 2020)

\section{Alat dan Objek Penelitian}

Alat penelitian yaitu cangkul, linggis tanah, polibag, kotak koleksi, kertas label, dan kamera Hand Phone android dilengkapi aplikasi google lens. Google lens dalam bidang biologi saat ini digunakan untuk pengenalan objek penelitian yaitu hewan dan tumbuhan dengan tingkat pengenalan objek sampai pada genus dan spesies (Shapovalov, et al., 2020) (Gambar 2).

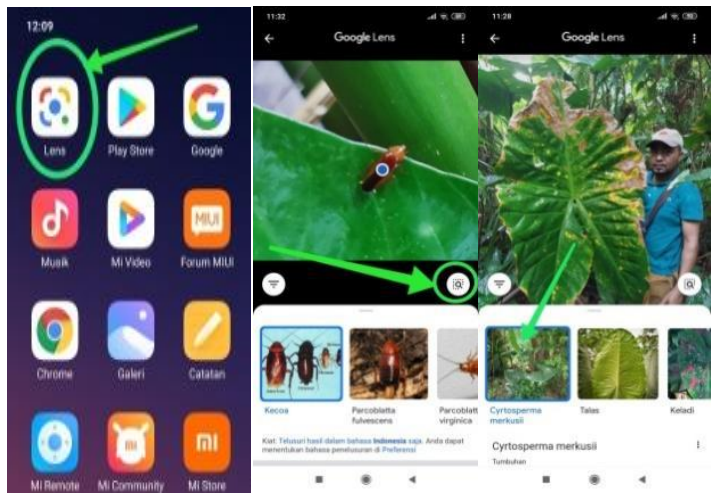

Gambar 2. Pengenalan objek menggunakan aplikasi google lens.

\section{HASIL DAN PEMBAHASAN}

\section{Morfologi dan Identifikasi Hama}

Dalam penelitian karakter morfologi dan identifikasi hama pada tanaman dalugha ditemukan jenis-jenis hama pada tanaman dalugha di Desa Moronge Kepulauan Talaud Provinsi Sulawesi Utara yang dapat diklasifikasikan dalam tiga kelas sebagai berikut:

\section{Kelas Gastropoda}

Morfologi dan identifikasi jenis-jenis hama yang tergolong dalam kelas Gastropoda antara lain:

\subsection{Bekicot (Achatina fulica)}

Bekicot termasuk dalam kelompok moluska yang umumnya ditemukan pada lingkungan yang lembab dan kurang dari paparan sinar matahari langsung. Bekicot mempunyai kemampuan beradapatasi sangat baik pada berbagai kondisi lingkungan. Hewan bercangkang yang hidup di darat ini terdiri dari beberapa jenis dan salah satunya adalah bekicot. Bekicot jenis ini ditemukan pada daun tanaman dalugha yang masih hijau. Cangkang berwarna coklat dengan gelung melingkar berwarna coklat gelap. Dalam situasi tertentu bekicot mengulurkan tubuhnya dalam cangkang sebagai tempat persembunyian dari gangguan luar (Gambar $3)$. 


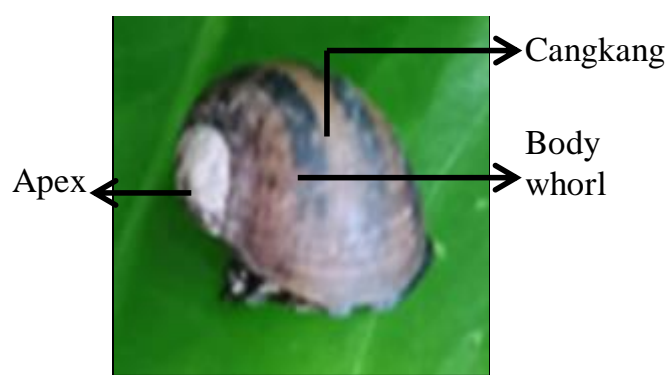

Gambar 3. Bekicot (Achatina fulica) pada daun dalugha

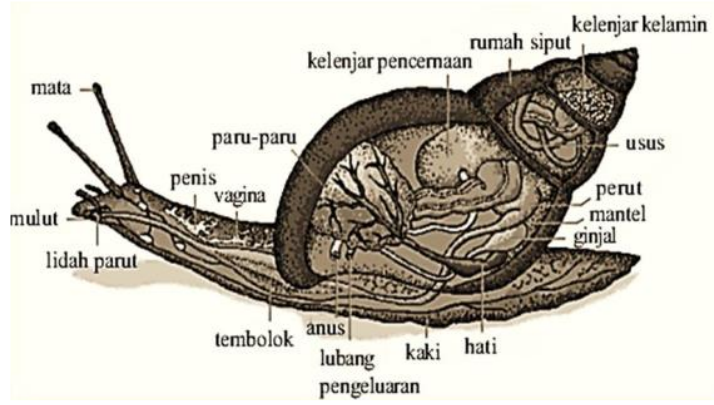

Gambar 4. Struktur tubuh bekicot.

( Sumber: e-journal.uajy.ac.id.)

Hasil pengamatan karakter morfologi bekicot (Achatina fulica) pada Gambar 3, sebagai berikut: tubuh bekicot terdiri dari struktur cangkang dan tubuh yang lunak. Cangkang bekicot umumnya berbentuk menyerupai tabung kerucut berbentuk spiral berwarna cokelat dan memiliki bercak berwarna gelap. Cangkang ini terdiri atas tiga bagian yaitu apex berbentuk kerucut pada puncaknya, bagian sumbu kerucut atau columella, dan gelung paling besar atau body whorl. Bekicot tidak mempunyai tulang belakang atau bertubuh lunak yang terlindung oleh cangkang dan dapat bersembunyi di dalamnya pada waktu tertentu.

Tubuh bekicot terdiri dari bagian kepala yang disebut caput dan perut yang disebut badan memiliki anus dari saluran pencernaannya. Kepala bekicot terbagi dua yaitu tentakel dan mulut, pada mulut bekicot terdapat celah mulut dan gigi-gigi halus yang disebut radula digunakan sebagai alat mulut pemakan daun tanaman. Bekicot ini juga memiliki lubang genital di sisi kanan bagian bawah kepala yang disebut sebagai muara organ genitalia yang berdekatan dengan photoreseptor sebagai tempat keluarnya penis. Pada bagian Gastropodus atau kaki perut berbentuk lebar, pipih, dan sangat rapat dan berfungsi sebagai alat gerak yang mengandung kelenjar yang menghasilkan lendir (Anonim, 2020a) (Gambar 4).

Berdasarkan karakter morfologi maka bekicot jenis ini dapat diklasifikasikan dalam family Achatinidae, genus Achatina dan tergolong dalam spesies Achatina fulica.

\subsection{Keong Semak (Bradybaena similaris)}

Keong semak merupakan salah satu hewan dari kelompok moluska yang ditemukan pada rerumputan yang tinggi, di bawah kayu atau ranting dan di hutan tanaman dalugha. Jenis siput ini berukuran kecil yang ditemukan pada tanaman dalugha dan sekitarnya pada lingkungan yang gelap dan lembab. Keong semak terlihat berjalan perlahan berada di atas permukaan daun sambil memakan jaringan daun tanaman. Keong semak jenis ini bila berada di tanah maka dapat memakan akar tanaman yang masih muda dan bila berkelanjutan maka akan menyebabkan gangguan fungsi akar tanaman (Gambar 5).

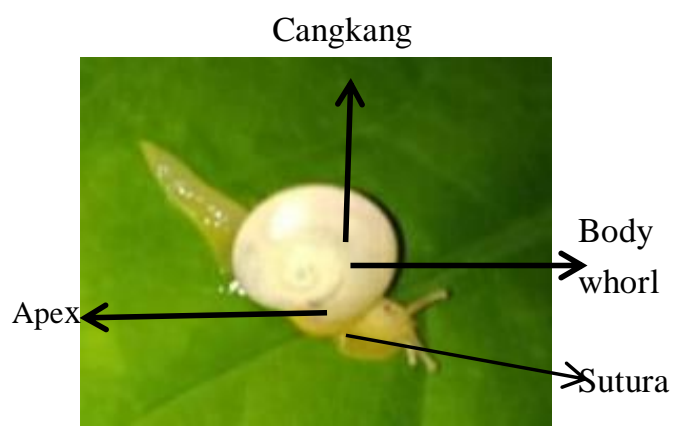

Gambar 5. Keong Semak (Bradybaena similaris) pada daun dalugha.

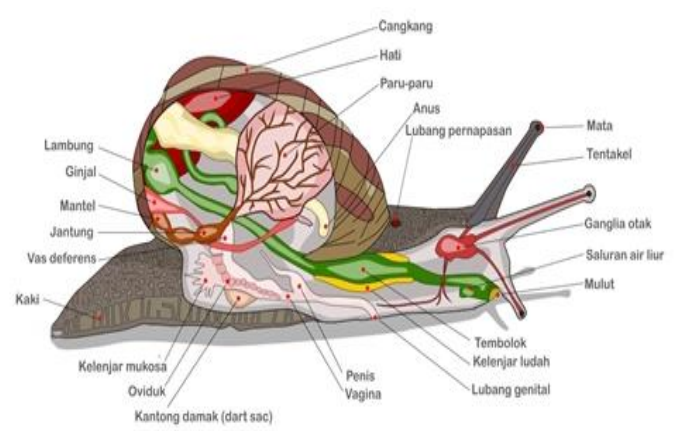

Gambar 6. Struktur tubuh Keong semak (Bradybaena similaris)

(Sumber: Google. Rebanas.com)

Gambar 6 memperlihatlan karakter morfologi keong semak sebagai berikut: Keong Semak (Bradybaena similaris) memiliki cangkang bundar dan cembung berwarna coklat keputih-putihan. Warna tubuhnya kuning keemasan dan sangat indah 
berkilauan. Keong semak mempunyai 5-6 alur lingkaran.

Menurut Serniotti et al. (2019) gigi radular keong semak dewasa tersusun dalam sebuah garis agak lurus dengan 125-146 baris, dan 32-35 gigi per setengah baris. Gigi bagian tengah agak lebih kecil dari lateral pertama sedangkan pelat basal gigi tengah simetris dan trapezium dengan ekstensi basal lateral yang terangkat pada sudut yang tajam. Keong jenis ini diketahui menjadi inang bagi cacing parasit Eurytrema pancreaticum yang merupakan penyebab radang pankreas pada kerbau, sapi, biri-biri, babi, dan kambing. Keong semak merupakan keong darat berukuran kecil yang ditemukan juga pada tanaman dalugha. Dalam keadaan lingkungan yang gelap dan lembab, keong semak berjalan perlahan berada di atas permukaan daun sambil memakan jaringan daun tanaman. Berdasarkan karakter morfologi maka keong semak tergolong dalam family Bradybaenidae, genus Bradybaena dan diklasifikasikan sebagai siput dalam spesies Bradybaena similaris.

\subsection{Siput Hijau (Rhinocochlis nasuta)}

Siput hijau sesuai dengan namanya memiliki cangkang berwarna hijau terang merupakan salah satu jenis siput dari kelompok moluska. Siput jenis ini ditemukan di hutan tanaman dalugha dengan kondisi lingkungan yang lembab dan kurang dari paparan sinar matahari.

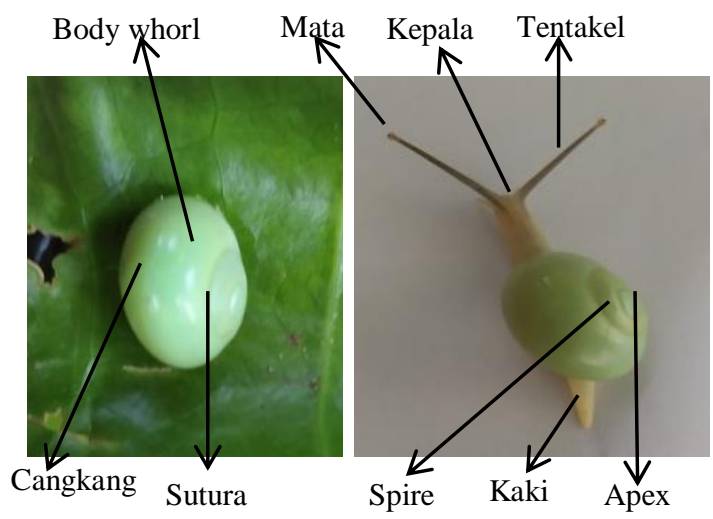

Gambar 7. Siput Hijau (Rhinocochlis nasuta)

Siput hutan jenis ini memiliki cangkang melingkar dengan spiral cembung berbentuk kerucut. Menurut Panhal \& Ung (2001) Siput ini merupakan jenis siput hijau yang indah dan langkah berasal dari Sarawak Kalimantan. Siput ini termasuk genus Rhinocochlis diberi nama oleh Thiele untuk sepasang spesies
Borneo terkini. Thiele terdaftar sebagai sebuah spesies genus Helix masuta Metcalfe yang termasuk jenis spesies monotip dalam anggota dari famili siput darat pulmonata, Ariophantidae. Ukuran tubuh siput hijau sekitar 0,5-3 cm dengan diameter cangkang yang diberikan oleh Thiele adalah 30-36 mm. Tubuhnya berwarna kuning keabu-abuan (Gambar 7).

Panhal \& Ung (2001) juga berpendapat bahwa penampakan jenis siput Rhinocochlis nasuta berasal dari pigmentasi hijau bagian luar siput yang masih hidup dan bukan karena pigmentasi cangkangnya.Warna cangkang sebenarnya dari cangkang tipis yang agak transparan berwarna coklat. Siput ini tidak memiliki umbilicus dengan bibir luar tipis dan di tepi distal membentuk tonjolan hidung modus. Berdasarkan karakter morfologi maka siput jenis ini dapat diklasifikasikan sebagai siput dalam famili Dyakiidae, genus Rhinocochlis, dan spesies Rhinocochlis nasuta.

\subsection{Siput Pita/ Banded Caracol (Caracolus marginella)}

Berdasarkan hasil pengamatan karakter morfologi tubuh siput pita pada Gambar 8 dapat dijelaskan sebagai berikut: siput pita memiliki cangkang yang melingkar ke arah kanan searah jarum jam bila dilihat dari ujung puncak atau apex. Cangkak berbentuk bulat melingkar tipis dan memiliki spire dan body whorl yang kecil dan sempit dengan sutura yang terbentuk antara spire. Pada bagian belakang cangkang terdapat lubang tempat keluar masuknya kepala dan kaki yang disebut Aperture.

Menurut Auffenberg et al. (2011) siput pita (Caracolus marginella) memiliki cangkang yang besar sekitar 35-45 mm. Siput jenis ini memiliki lenticular atau depresitrochoid dalam bentuk dan tajam terjungkal di pinggiran lingkaran tubuh. Ada lima sampai enam lingkaran secara bertahap mengembang dan dasarnya sedikit membengkak. Area pusar agak cekung, dengan umbilicus kadangkadang ditutup oleh bibir columellar yang dipantulkan. Kulit patung relatif halus dengan garis pertumbuhan yang tidak teratur.

Tubuh whorl turun hampir vertikal tepat sebelum aperturenya dengan bibir aperture yang sangat menebal di dalamnya. Aperture dipantulkan ke belakang dan ke atas dan ke belakang pinggiran dengan kalus parietal yang 
menebal. Spesimen yang terlihat segar memiliki periostracumtan, biasanya terkikis dari puncak menara, dengan warna coklat muda dan coklat tua ke pita putih dengan lebar dan intensitas warna yang bervariasi, biasanya berwarna putih sedangkan bibir apertural, kalus parietal dan columella berwarna mawar, putih, atau kecoklatan. Siput ini diperkenalkan pertama kali di Florida oleh Clapp tahun 1919, Caracolus marginella adalah spesies yang sangat berbeda dan tidak dapat disamakan dengan spesies lain karena ukurannya dan pola warna berpita yang dimilikinya. Hasil pengamatan berdasarkan karakter morfologi menunjukkan bahwa siput jenis ini tergolong dalam family Pleurodontidae, genus Caracolus, dan spesies Caracolus marginella.

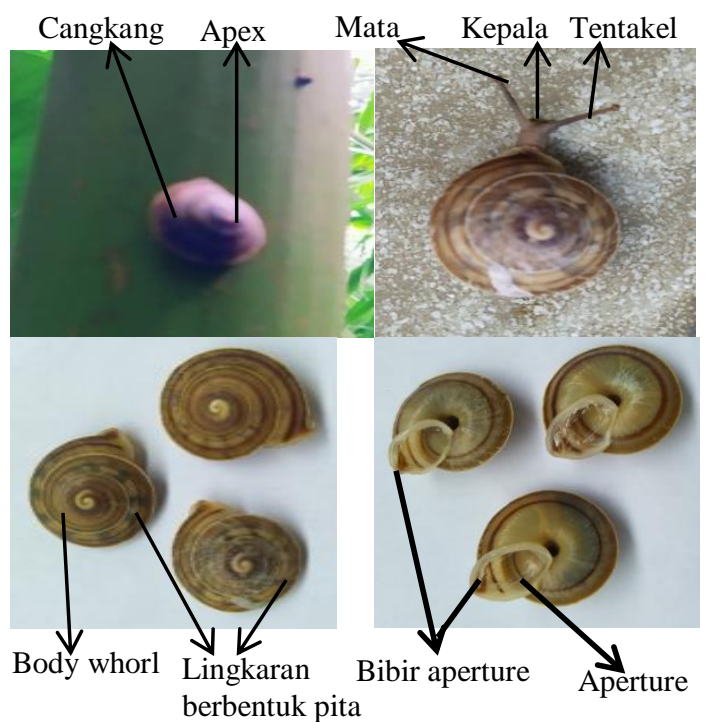

Gambar 8. Siput Pita/ Banded Caracol (Caracolus marginella) pada pelepah dalugha

\subsection{Siput Kebun (Cornu aspersum)}

Hasil pengamatan jenis siput ini merupakan salah satu hewan dari kelompok moluska yang ditemukan di hutan tanaman dalugha. Siput jenis ini memiliki tubuh lembut dan berlendir dengan warna yang indah kuning keemasan (Gambar 9). Siput darat ini memiliki sebuah cangkang sebagai rumahnya dan dapat menarik seluruh tubuhnya ke dalam cangkang bila tidak aktif atau ada ancaman dari luar.

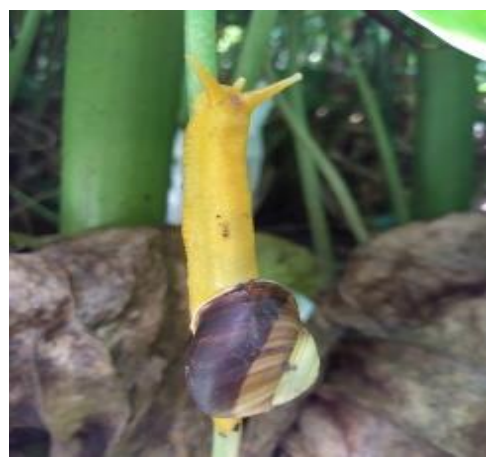

Gambar 9. Siput Kebun (Cornu aspersum) pada batang dalugha

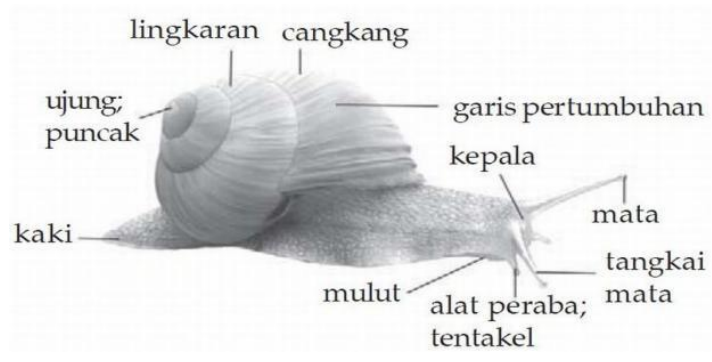

Gambar 10. Struktur tubuh Siput kebun

(Sumber:https://agungwibowojogja.wordpress.co $\mathrm{m} /$ tag/ternak-bekicot/)

Siput dewasa memiliki cangkang keras dan tipis dengan empat atau lima ulir. Cangkang bervariasi dalam pewarnaan dan bayangan warna, tetapi umumnya memiliki pola retikulasi coklat tua, emas kecoklatan, atau kastanye dengan garis-garis kuning, bintik-bintik, atau guratan. Siput ini memiliki aperture besar dan miring dengan margin pada siput dewasa berwarna keputihan dan dipantulkan (Gambar 10).

Ketika terluka atau teriritasi parah, siput menghasilkan buih lendir pertahanan yang mungkin mengusir beberapa musuh atau membanjiri semut kecil yang agresif dan sejenisnya. Siput tidak memiliki operculum sehingga siput menutup lubang cangkang dengan selaput tipis lendir kering sepanjang cuaca kering atau dingin. Selaput tipis berlendir ini dikenal dengan istilah epiphragm yang berfungsi membantu siput mempertahankan kelembaban dan melindunginya dari predator kecil seperti semut.

Kepala siput memiliki empat tentakel dengan dua bagian atas lebih besar dan memiliki sensor cahaya seperti mata yang sangat kecil dan dua bagian bawah adalah organ indra peraba dan penciuman. Siput memperpanjang tentakel dengan tekanan internal cairan tubuh, dan menarik keempat 
tentakel ke kepala dengan invaginasi saat terancam atau mundur ke dalam cangkangnya. Mulut siput ini terletak pada bagian bawah tentakel yang berisi radula kitinus. Alat mulut siput inilah yang digunakan untuk mengikis dan memanipulasi partikel makanan (Anonim, 2020b). Berdasarkan karakter morfologi siput ini tergolong dalam family Helicidae, genus Cornu, dan spesies Cornu aspersum.

\subsection{Sumpil (Subulina octona)}

Siput jenis ini merupakan siput darat dalam filum moluska dengan ukuran tubuh yang paling kecil. Siput ini kebanyakan ditemukan di serasah daun dan materi tanaman yang membusuk. Hasil pengamatan sumpil ini paling banyak ditemukan pada bagian bawah umbi dalugha yang membusuk (Gambar 11).
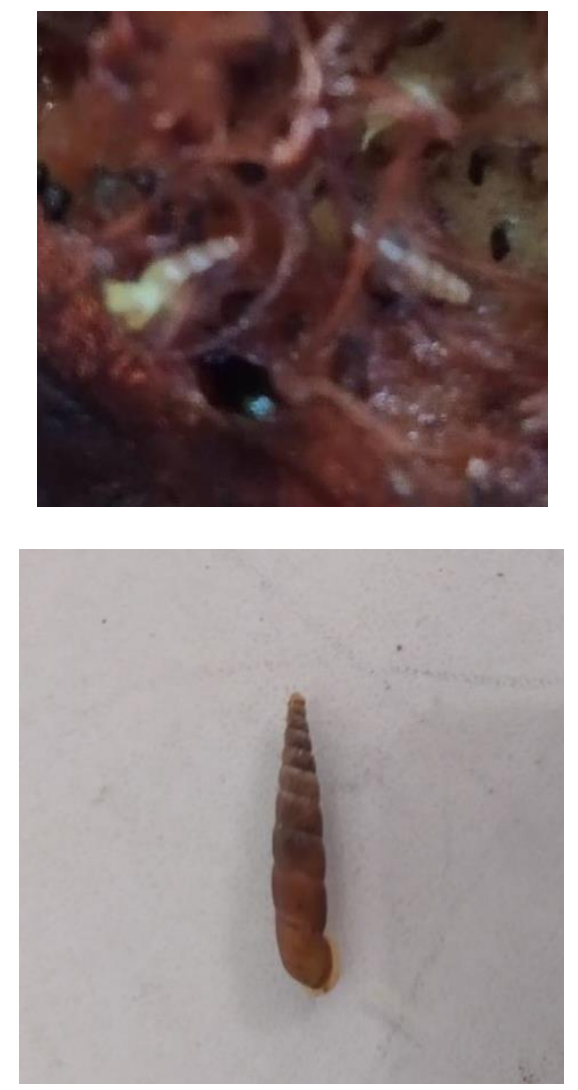

Gambar 11. Sumpil (Subulina octona) pada umbi dalugha yang membusuk.

Sumpil dewasa dapat bergerak mencari makanan pada batang dan daun tanaman dalugha. Tubuhnya berwarna kuning dan memiliki kontur tubuh yang lembut. Siput jenis ini memiliki cangkang berukuran kecil dan memanjang. Cangkang sumpil berbentuk langsing menyerupai gulungan benang dengan seluk sekitar 9-10. Dinding cangkang melingkar sempurna terlihat mengkilap dan transparan dengan garis taut atau sutura terlihat jelas tetapi sedikit mengerut. Pada puncak cangkang terlihat tumpul dan dasar seluk membulat serta pusar atau umbilikus tertutup (Gambar 12).

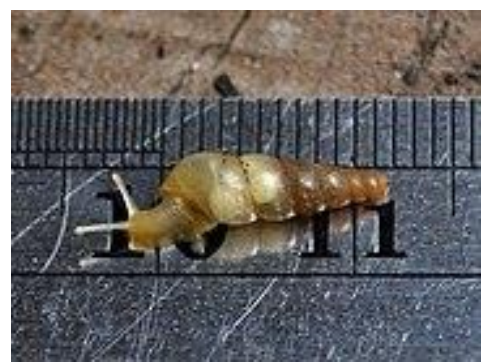

Gambar 12. Penelusuran google Sumpil (Subulina octona)

(Sumber: Wikipedia)

Mulut cangkang pada siput jenis ini terlihat agak miring, berbentuk lonjong dan meruncing di bagian atas dan bawah. Bagian tepi mulut cangkang terlihat agak tajam dan tidak menebal atau melipat. Pada bagian sumbu cangkang atau kolumela terpangkas di bagian bawah. Cangkang sumpil berwarna kuning tanduk dengan garis lebih tua sepanjang sumbu cangkang. Tubuhnya yang kecil membuat pergerakannyapun sangat lamban (Anonim, 2020c). Siput jenis ini dikelompokkan dalam family Subulinidae, genus Subulina. Siput ini diklasifikasikan sebagai jenis siput dalam spesies Subulina octona.

\section{Kelas Insekta}

Karakter morfologi dan identifikasi jenis-jenis hama pada tanaman dalugha yang tergolong dalam kelas Insekta dapat diuraikan sebagai berikut:

\subsection{Belalang Hijau (Oxya servile)}

Hasil pengamatan belalang jenis ini memiliki tubuh berwarna hijau terang termasuk dalam kelompok filum Atrhopoda. Terlihat sepasang belalang hijau berada pada jaringan daun dan tangkai daun dalugha (Gambar 13). Pada bagian tengah atas tubuhnya terdapat adanya garis berwarna hijau kekuningan. Belalang hijau mempunyai garis berwarna kehitaman pada bagian sisi tubuhnya dari mata menuju sayap depan (Gambar 14). 


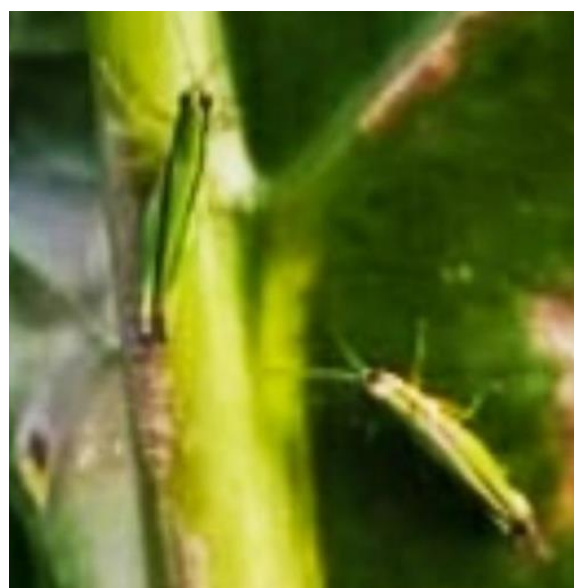

Gambar 13. Belalang hijau (Oxya servile) pada daun dalugha.

Pada penelusuran melalui google ditemukan gambar jenis belalang hijau yang lebih jelas dengan struktur tubuh yang tertera pada Gambar 14 dan 15.

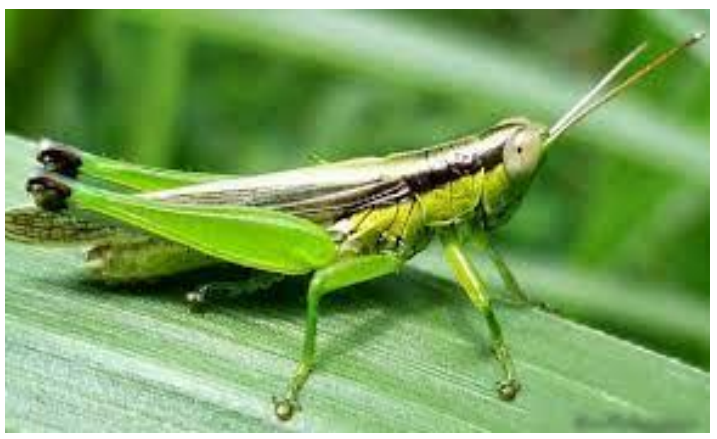

Gambar 14. Belalang hijau

(Sumber:Jenis Belalang (Page 1)Line.17QQ.com)

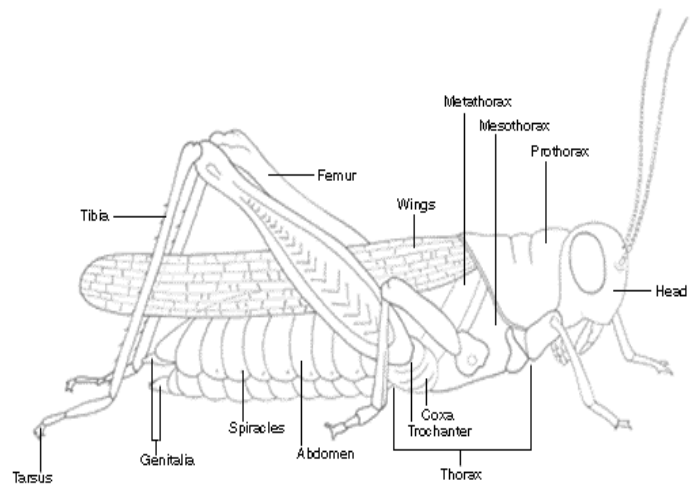

Gambar 15. Struktur tubuh belalang

(Sumber: www.kajianpustaka.com)

Belalang hijau memiliki tubuh yang terdiri atas tiga bagian utama yaitu kepala atau caput, dada atau thoraks, dan perut atau abdomen. Pada bagain kepala terdapat sepasang antena berukuran pendek yang berfungsi sebagai mekanosensorik dan kemosensorik. Pada bagian kepala juga terdapat sepasang mata majemuk dan tiga buah mata ocelli. Mulut belalang hijau terdiri atas tiga pasang alat bantu yaitu sepasang mandibula, sepasang labium, sepasang maksila, dan memiliki hipofaring. Belalang hijau (Oxya servile) tergolong dalam serangga dengan tipe alat mulut penggigit dan pengunyah (Gambar 15).

Belalang hijau memiliki dua jenis organ gerak yaitu sayap dan kaki di mana sayap melekat pada bagian dada di segmen kedua yaitu mesothorax dan segmen ketiga yakni metathorax. Bagian kaki terletak pada tiap segmen dada dan sepasang kaki belakang digunakan untuk melompat. Pada setiap segmen abdomen dan dadanya terdapat sepasang lubang spirakel sebagai tempat keluar masuknya udara untuk pernapasan. Sistem pernapasannya disebut sistem trakea di mana udara masuk ke dalam tubuh serangga melalui lubang spirakel kemudian melalui saluran trakea dan trakeolus menyebar ke seluruh tubuh sampai ke jaringan tubuh. Pada jaringan tersebut terjadi pertukaran gas dan proses pertukaran gas ini dibantu oleh sistem sirkulasi darah (Anonim, 2020d). Berdasarkan karakter morfologi, belalang hijau termasuk dalam family Acrididae, genus Oxya, dan spesies Oxya servile.

\subsection{Jangkrik semak (Tettigonia caudate)}

Pengamatan pada tubuh jangkrik termasuk dalam kelompok serangga dalam filum Arthropoda. Jangkrik jenis ini mempunyai kemiripan dengan belalang namun ada perbedaan yang jelas terlihat yaitu jangkrik (Tettigonia caudate) memiliki antena yang lebih panjang dari pada belalang. Pada ruas abdomen terakhir jangkrik mempunyai cerci lebih panjang dari pada belalang. Jangkrik jenis ini memiliki tubuh berwarna hijau ditemukan pada hutan tanaman dalugha (Gambar 16). 


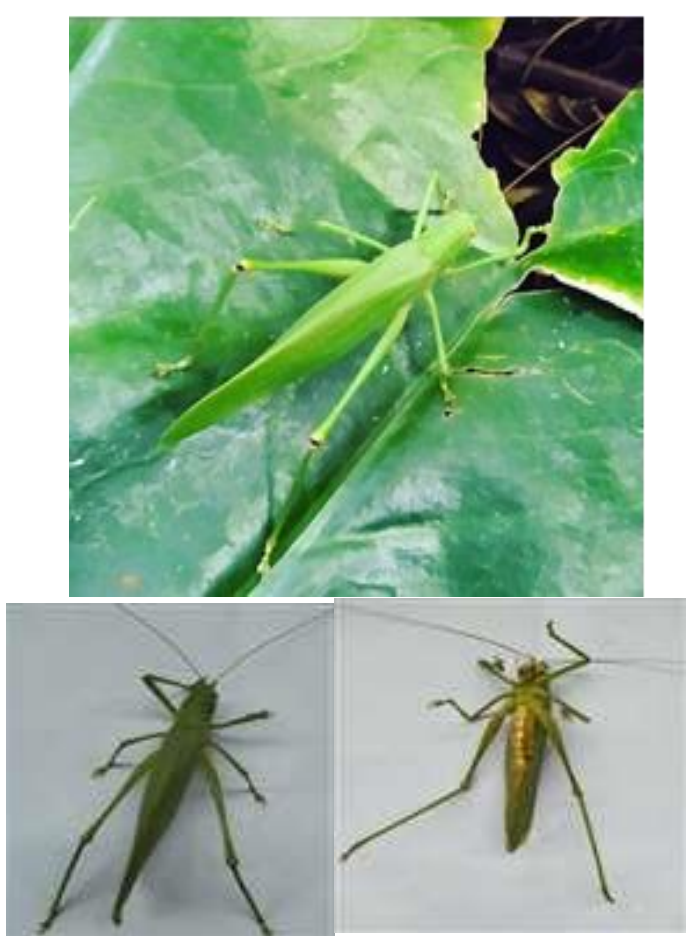

Gambar 16. Jangkrik semak (Tettigonia caudate)

Keterangan mengenai struktur tubuh jangkrik dapat dilihat pada Gambar 18 di bawah ini.

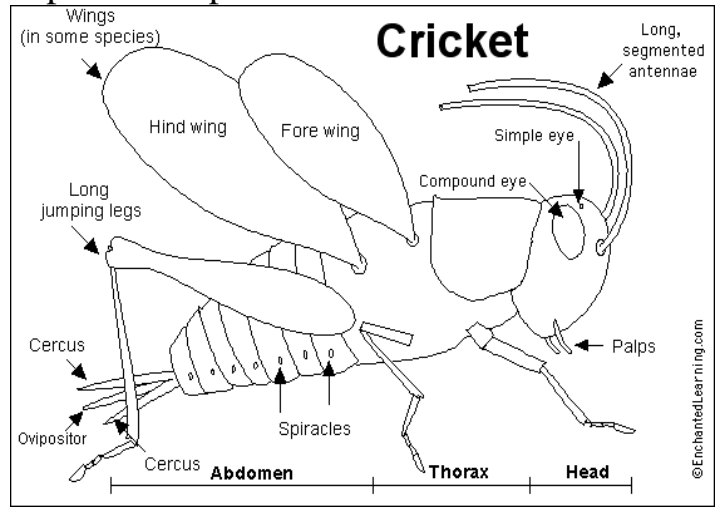

Gambar 17. Struktur tubuh jangkrik

(Sumber: https://erakini.com/ jangkrik -ini-10-fakta).

Berdasarkan pengamatan morfologi tubuh jangkrik pada Gambar 17, dapat diuraikan sebagai berikut: Tubuh jangkrik semak terdiri atas tiga bagian utama yaitu kepala, toraks, dan abdomen. Pada bagian kepala terdapat mata tunggal sepasang antena, satu mulut, dan dua pasang sungut. Bagian toraks merupakan tempat melekatnya empat sayap dan enam tungkai. Abdomen pada bagian posterior terdiri atas ruas-ruas dan bagian ujung abdomen terdapat sepasang cerci yang panjang dan tajam. Cerci ini berfungsi sebagai penerima rangsang atau pertahanan apabila ada gangguan dari belakang. Pada jangkrik betina memiliki ovipositor lebih panjang dari jantan yang muncul dari ruas abdomen terakhir. Pada bagian sayap depan jangkrik betina berbentuk garis-garis lurus sedangkan pada jangkrik jantan memiliki venasi berbentuk garis- garis lurus dan melingkar (Erniwati, 2012). Berdasarkan karakter morfologi, jangkrik jenis ini tergolong serangga dalam family Tettigoniidae,genus Tettigonia, dan termasuk dalam spesies Tettigonia caudate.

\subsection{Kumbang Daun (Asphaera lustrans)}

Pengamatan kumbang jenis ini merupakan salah satu hewan dalam kelompok Arthtopoda. Kumbang ini memiliki tubuh hitam mengkilap sedangkan kepala antena dan kaki berwarna orange. Pada bagian kaki belakang terlihat berukuran lebih besar. Kaki belakang yang besar ini berfungsi untuk melompat dan bergerak mencari makanan pada daun tanaman dalugha (Gambar 18).

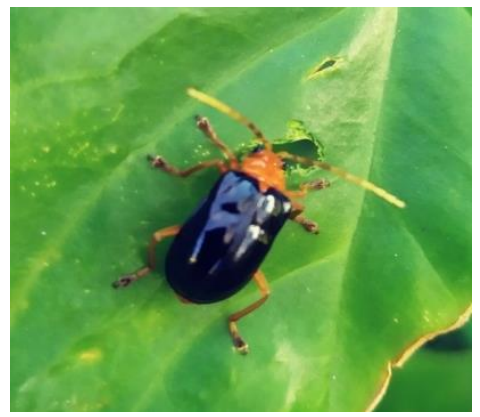

Gambar 18. Kumbang Daun (Asphaera lustrans) pada daun dalugha

Pengamatan morfologi tubuh kumbang daun dan struktur tubuh kumbang daun dapat dilihat pada Gambar 19.

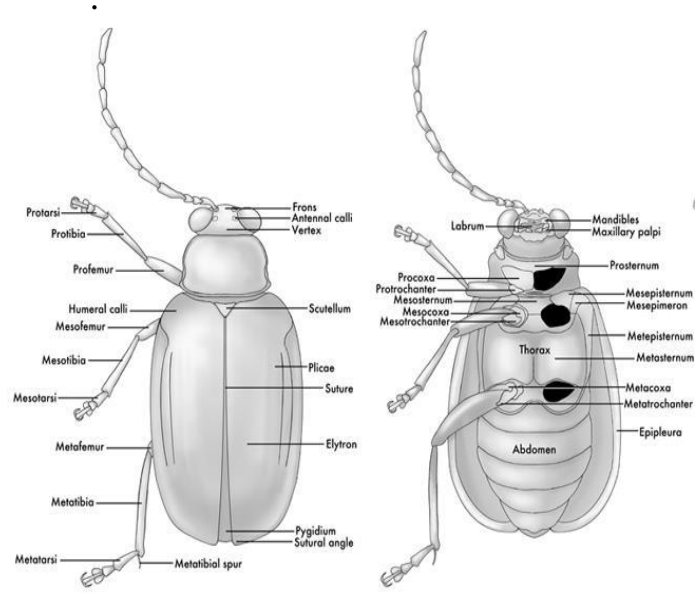

Gamabr 19. Struktur tubuh kumbang daun (Sumber: repository.unpas.ac.id) 
Asphaera lustrans lebih dikenal dengan kumbang kutu mengkilap karena memiliki tubuh hitam mengkilap. Kumbang daun berukuran kecil hingga sedang dan ada beberapa spesies yang berukuran lebih besar seperti Alurnus humeralis. Tubuh sebagian besar spesies berbentuk kubah dan berbentuk oval pada bagian punggung ada beberapa berbentuk bulat atau memanjang dan sering kali memiliki warna berkilau logam atau berwarna-warni. Pada kebanyakan spesimen, antena pada umumnya lebih pendek dari kepala, dada, dan perut. Ruas antena kedua berukuran normal (Gambar 19).

Segmen antena pada kumbang daun memiliki bentuk yang kurang lebih sama dan kebanyak melebar ke arah ujung meskipun beberapa Galerucinae secara khusus telah memodifikasi segmen mereka terutama pada kumbang jantan. Dalam banyak kasus, segmen antena pertama lebih besar dari segmen yang lainnya. Pronotum kumbang daun bervariasi antar spesies, sebagian besar bentuknya agak berkubah tinggi dan berbentuk trapesium hingga persegi bulat dalam tampilan punggung. Di beberapa subfamily seperti Cassidinae dan Cryptocephalinae kepalanya ditutupi oleh pronotum sehingga tidak terlihat dari atas. Sebagian besar spesies memiliki sayap, meskipun tingkat perkembangan dan kemampuan terbang sangat bervariasi, termasuk dalam satu spesies, dan beberapa tidak dapat terbang dengan elytra yang menyatu.

Berdasarkan karakter morfologi, kumbang ini termasuk dalam family Chrysomelidae dan tergolong dalam genus Asphaera. Hasil pengamatan morfologi pada kumbang jenis ini termasuk dalam spesies Asphaera lustrans.

\subsection{Kepik Kaki Daun Tumbuhan/leaf-footed plant bug (Leptoglossus australis)}

Pengamatan morfologi kepik kaki daun tumbuhan ini termasuk salah satu kelompok hewan dalam filum Arthropoda. Kepik Kaki daun tumbuhan ditemukan pada daun tanaman dalugha. Kepik yang satu ini secara morfologi berwarna coklat keabu-abuan dan memiliki kaki belakang agak melebar seperti daun (Gambar 20). Sewaktu-waktu kepik kaki daun mengeluarkan aroma tidak sedap bila mendapat ancaman atau gangguan luar.

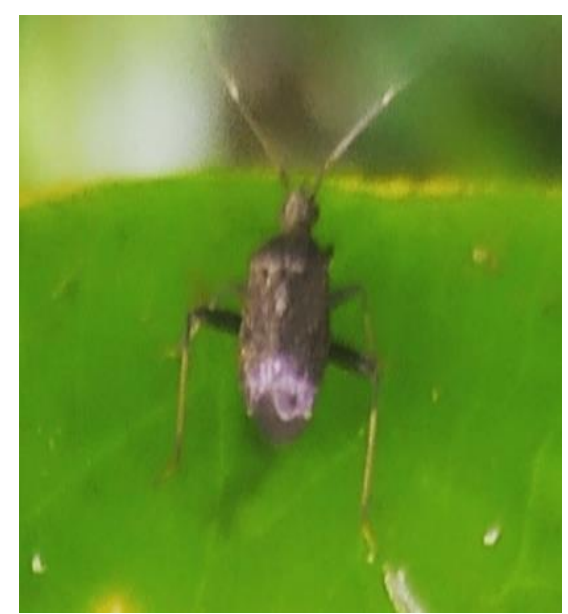

Gambar 20. Kepik Kaki Daun Tumbuhan (Leptoglossus australis)

Pengamatan morfologi tubuh kepik kaki daun tumbuhan terlihat pada Gambar 21.

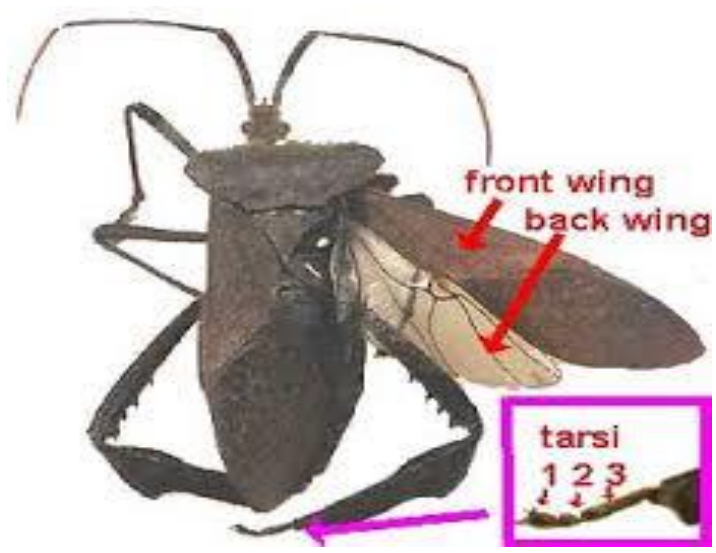

Gambar 21. Struktur tubuh Kepik Kaki Daun Tumbuhan.

(Sumber: Biologyjunction.com)

Kepik kaki daun dewasa berwarna cokelat gelap dan memiliki sayap datar dan lurus ke arah belakang pada saat menutupnya. Antena kepik kaki daun terdiri atas empat ruas dan mempunyai tipe alat mulut pencucuk dan penghisap yang terdiri atas empat ruas. Kepik jantan mempunyai ruas kaki membesar dan memipih dan pada betis atau tibia kaki belakang agak melebar menyerupai daun. Bagian sayap depan kepik jenis ini berbentuk seperti kulit. Pada bagian depan pronotum kepik kaki daun tumbuhan (Leptoglossus australis) memiliki garis melengkung berwarna oranye kemerahan atau kuning. Bentuk tubuh kepik ini memanjang dengan bentuk ukuran kepala lebih pendek dan lebih sempit dari pada pronotum. Nimfa Leptoglossus australis berwarna kemerahan 
pada instar awal dan lebih menyukai inang tumbuhan liar. Nimfa kaki daun berkembang mulai pada instar ketiga dan instar keempat mulai terlihat mempunyai bercak kuning dan hitam dan pada instar kelima berwarna cokelat gelap atau hitam. Telur Leptoglossus australis berbentuk agak silindris dengan warna mulamula hijau cerah kemudian berubah menjadi warna cokelat dan coklat terang (Gambar 21).

Berdasarkan karakter morfologi, kepik kaki daun tumbuhan tergolong dalam family Coreidae, genus Leptoglossus, dan termasuk dalam spesies Leptoglossus australis.

\subsection{Kutu Kebul (Bemisia tabaci)}

Kutu kebul jenis ini merupakan serangga yang berukuran kecil dan berwarna putih termasuk kelompok filum Arthropoda. Serangga ini merupakan salah satu dari beberapa spesies kutu putih yang teridentifikasi sebagai hama pertanian penting termasuk tanaman dalugha. Terlihat kutu kebul berdiam di bawah permukaan daun dalugha sekaligus menjadi tempat memperoleh makanan dan meletakan telur (Gambar 22).

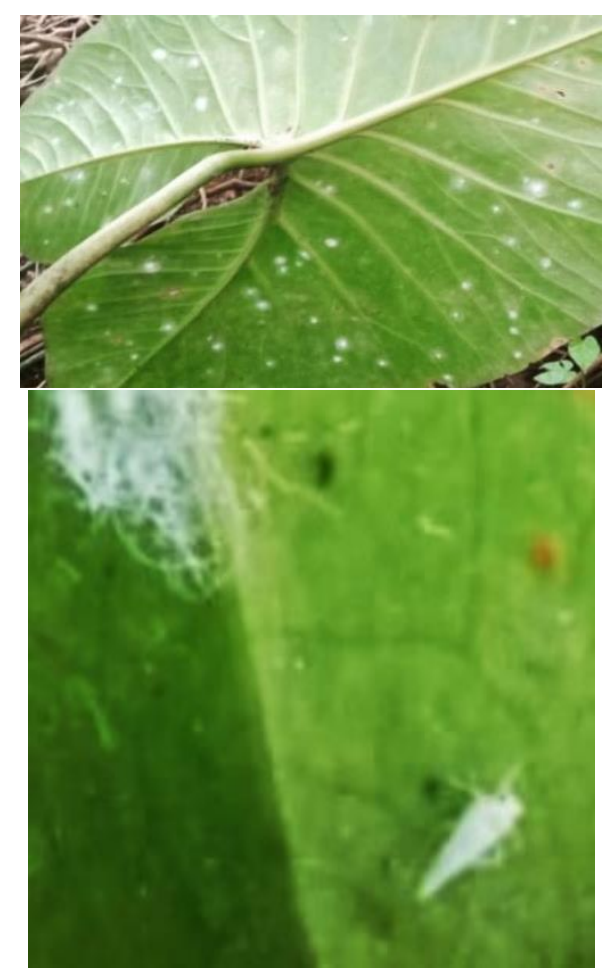

Gambar 22. Kutu Kebul (Bemisia tabaci) pada daun dalugha.

Gambar kutu kebul lebih jelas terlihat pada Gambar 23 dalam sebuah penelusuran google.

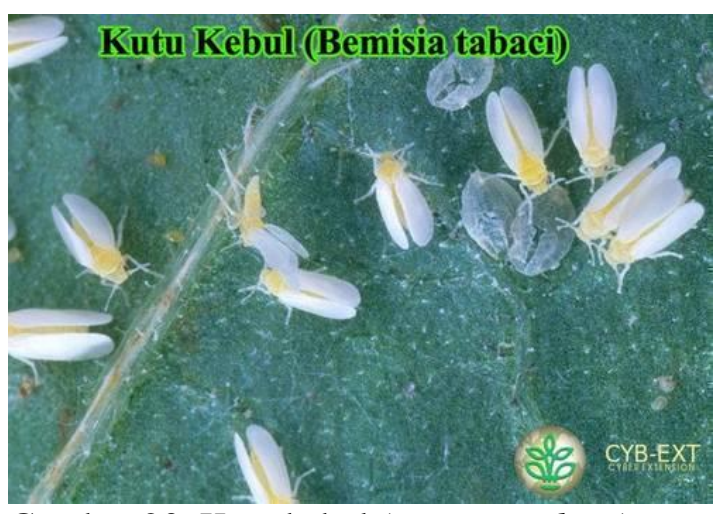

Gambar 23. Kutu kebul (Bemisia tabaci)

(Sumber:https://8villages.com/full/petani/article/i d/5832a6216d3bd2e23a535208)

Nimfa kutu kebul jenis ini terdiri atas tiga instar, pada instar pertama bentuknya bulat telur dan pipih berwarna kuning kehijauan serta memiliki tungkai yang berfungsi untuk bergerak. Instar kedua dan ketiga tidak memiliki tungkai untuk bergerak dan selama pertumbuhannya, nimfa ini hanya melekat pada permukaan bawah daun. Nimfa kutu kebul memiliki stadium rata-rata sekitar 8-9 hari sedangkan kutu kebul dewasa atau imago mempunyai ukuran tubuh antara $1-1,5$ $\mathrm{mm}$. Imago terlihat berwarna putih dan mempunyai sayap yang ditutupi lapisan lilin yang bertepung putih. Siklus hidup dari kutu ini dimulai dari telur, nimfa kemudian menjadi kutu kebul dewasa dengan rentang waktu sekitar 21-24 hari. Dan selama masa hidupnya selalu menetap di bagian bawah permukaan daun tanaman (Gambar 23).

Identifikasi serangga jenis ini dapat diklasifikasikan dalam kelompok serangga kutu putih dalam family Aleyrodidae dan genus Bemisia. Berdasarkan karkater morfologi kutu putih, maka dapat digolongkan dalam jenis kutu kebul dalam spesies Bemisia tabaci.

\subsection{Semut Kebun Hitam (Lasius niger)}

Semut kebun hitam adalah salah satu dari jenis semut yang termasuk dalam filum Arthropoda. Semut ini merupakan serangga sosial karena hidupnya berkelompok dan tergolong dalam ordo Hymenoptera Semut kebun hitam ini disebut sebagai semut hitam umum karena ditemukan di berbagai tempat termasuk pada tanaman dalugha. Semut hitam jenis ini hidup berkoloni dan bekerja sama membentuk sebuah pertahanan yang kuat dan mempunyai kemampuan menyerang lawan atau musuh dari jenis hewan yang lebih besar. 
Pada tanaman dalugha ditemukan kelompok semut yang membuat sarangnya pada bagian bawah permukaan daun atau lipatan-lipatan daun (Gambar 24).

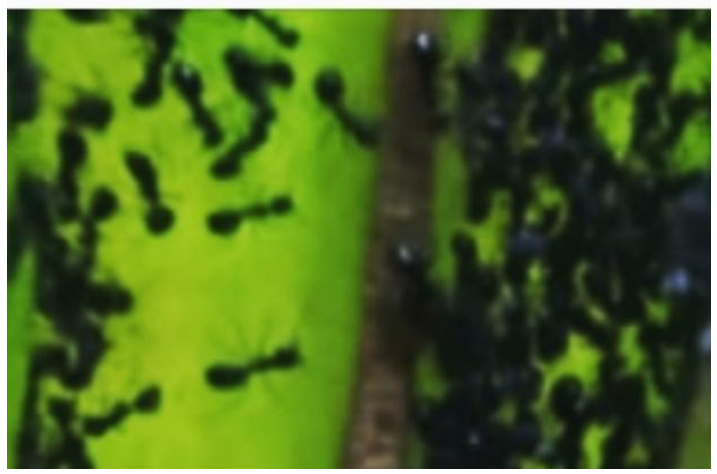

Gambar 24. Semut kebun hitam (Lasius niger) pada lipatan daun dalugha.

Pada penelusuran google ditemukan gambar semut yang jelas morfologinya yang dapat dilihat pada Gambar 25.

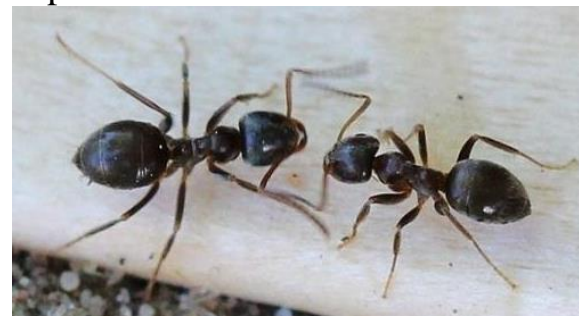

Gambar 25. Semut kebun hitam (Lasius niger).

(Sumber: https://bobo.grid.id/read/082117619/ semut-juga-melakukan-physical-distancing-saatada-yang-terinfeksi?page=all)

Keterangan struktur tubuh semut hitam dapat dilihat pada Gambar 26.

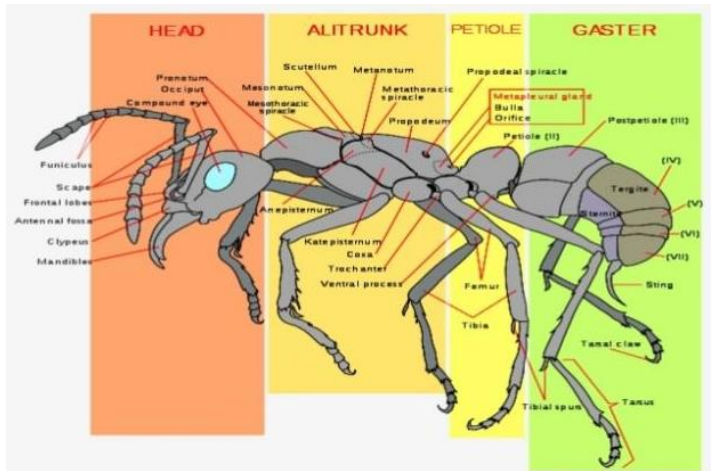

Gambar 26. Struktur tubuh semut kebun Hitam

(Sumber: https://www.seekpng.com)

Semut pekerja berwarna coklat tua atau hitam dengan corak keabu-abuan. Dada lebih ringan dari bagian tubuh lainnya. Kaki dan antenna termasuk segmen antena panjang pertama di dekat kepala dan tibia ditutupi dengan bulu lurus yang menonjol. Dada, kaki, rahang bawah, dan antena sedikit lebih ringan dari bagian tubuh lainnya dan memiliki warna kuning yang halus (Gambar 26).

Semut ratu berwarna hitam berbayang coklat. Segmen antena panjang pertama di dekat kepala dan tibia ditutupi dengan bulu lurus yang menonjol. Kepala selalu lebih ramping dari dada dan bersayap transparan. Semut jantan berwarna hitam berbayang coklat dan memiliki mandibula atau rahang dengan gigi pipih di dekat ujung runcing. Semut jantan memiliki sejumlah yang bervariasi, tetapi umumnya lebih sedikit daripada ratu. Jantan selalu memiliki bulu di tibia dan bersayap transparan (Anonim, 2020e). Berdasarkan karakter morfologi, semut kebun hitam tergolong dalam family Formicidae, genus Lasius, dan termasuk semut kebun hitam dalam spesies Lasius niger.

\subsection{Ulat Tanduk Talas/Taro Hornworm \\ (Theretra oldenlandiae)}

Ulat tanduk talas merupakan salah satu kelompok hewan dalam filum Arthropoda. Ulat jenis ini banyak ditemukan pada daun tanaman dalugha Pada umumnya ulat berada pada bagian bawah permukaan daun untuk mengindari diri dari serangan sinar matahari. Pada kondisi lingkungan yang lembab dan gelap, ulat ini akan bergerak menuju permukaan atas daun (Gambar 27).

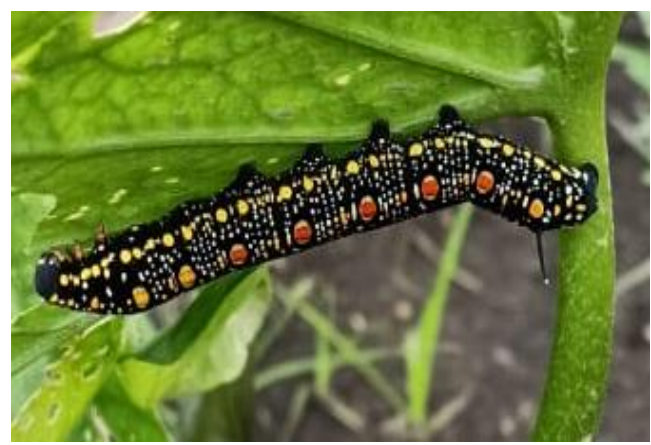

Gambar 27. Ulat tanduk talas (Theretra oldenlandiae) pada daun dalugha

Melalui penelusuran google ditemukan gambar ulat yang terlihat pada Gambar 28 . 


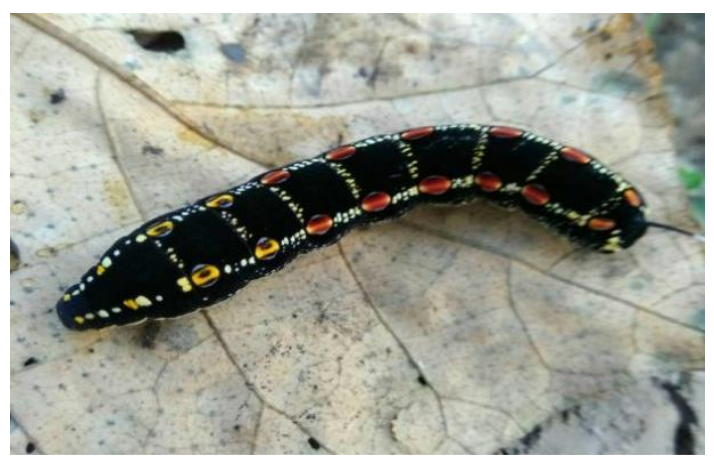

Gambar 28. Ulat tanduk talas (Theretra oldenlandiae)

(Sumber:https://steemkr.com/aceh/@ saifullah99/u lat-hitam-4973c8d4bab4b)

Berdasarkan pengamatan morfologi tubuh ulat tanduk pada Gambar 28, dapat dijelaskan sebagai berikut: ulat tanduk talas (Theretra oldenlandiae) pada instar kelima dan terakhir memiliki kepala kecil, kusam dan halus. Tubuh tumpul dan halus, kepalan meruncing dengan lembut lalu lebih tajam ke depan dari segmen delapan dan dengan lembut ke belakang dari segmen delapan, segmen ke empat dan lima tidak banyak bengkak. Theretra oldenlandiae memiliki tanduk lurus, panjang sedang, tipis, hampir silindris, ujung terpotong dengan menit, tuberkulum rendah di setiap sudut lateral, permukaan mengkilap, ditutupi dengan tuberkel yang sangat kecil. Ulat jenis ini memiliki tubuh berwarna hitam mengkilap. Terdapat bintik-bintik kuning pada punggung dan memiliki tanduk seperti ekor berwarna hitam membentuk busur yang dapat digerakan ke depan dan ke belakang. Berdasarkan karakter morfologi, ulat jenis ini termasuk dalam ordo Lepidoptera, family Sphingidae, genus Theretra dan tergolong dalam spesies Theretra oldenlandiae.

\subsection{Kecoa (Periplaneta americana L.)}

Kecoa disebut juga lipas atau coro adalah salah satu serangga dalam kelompok Arthropoda yang terdiri dari kurang lebih 4000 spesies di seluruh belahan bumi. Hasil pengamatan kecoa jenis ini merupakan salah satu serangga dalam filum Arthropoda. Ada beberapa jenis kecoa yang dianggap sebagai hama pada tanaman sedangkan yang lainnya diketahui bermanfaat untuk lingkungan. Kecoa memiliki hubungan dekat dengan serangga lainnya seperti rayap dan belalang sentadu. Kecoa jenis ini berwarna merah kecoklatan dan mengkilat. Kecoa ini banyak ditemukan di hutan tanaman dalugha
Kepulauan Talaud. Terlihat kecoa berada pada daun dalugha dan bergerak cepat dan bersembunyi di balik daun dan di tempattempat yang gelap (Gambar 29).

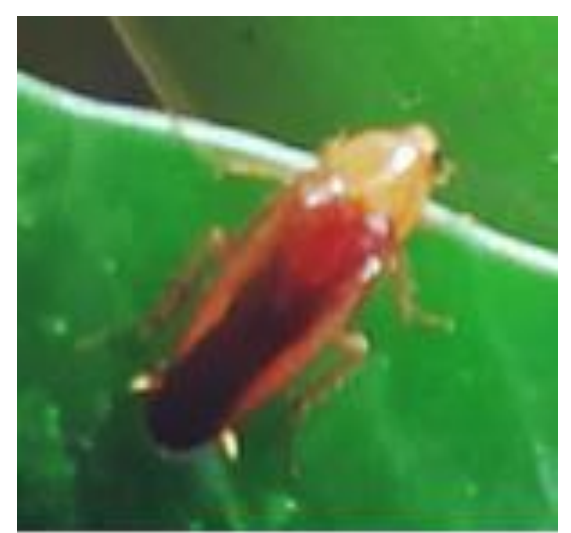

Gambar 29. Kecoa (Periplaneta Americana L.) pada daun dalugha

Struktur tubuh kecoa dapat dilihat pada Gambar 30.

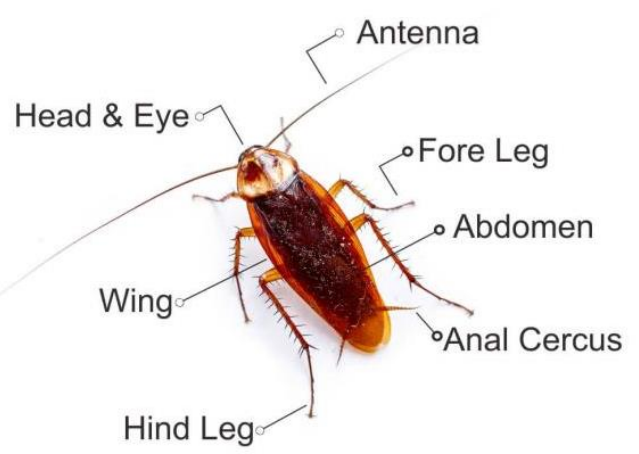

Gambar 30. Struktur tubuh kecoa (Periplaneta americana $\mathrm{L}$.)

(Sumber: https://haracare.id/bagaimana-strukturdari-anatomi-tubuh-kecoa/)

Kecoa jenis ini menunjukkan ciri morfologi serangga dengan bagian tubuh yang menyandang bagian kepala, badan, dan perut. Badan atau toraks dapat dibagi menjadi prothorax, mesothorax dan metathorax. Setiap segmen pada toraks memunculkan sepasang pelengkap berjalan yang dikenal sebagai kaki kursor. Organisme ini memiliki dua pasang sayap. Pada bagian sayap depan muncul dari mesothorax yang sebut sebagai tegmina berwarna gelap dan buram. Sayap belakang muncul dari metathorax dan digunakan untuk terbang meskipun kecoak jarang terbang. Perut terbagi menjadi 10 segmen di mana masing-masing segmen dikelilingi oleh pelat eksoskeleton kitin yang disebut sklerit, termasuk tergites punggung, pleurit lateral dansternit ventral. Berdasarkan karakter 
morfologi, kecoa ini tergolong dalam family Blattidae dan genus Periplaneta. Hasil identifikasi morfologi serangga jenis ini tergolong kecoa dalam spesies Periplaneta americana L (Gambar 30).

\subsection{Kecoa Surinam (Pycnoscelus surinamensis)}

Kecoa surinam merupakan salah satu dari berbagai jenis kecoa dari kelompok Arthropoda yang ditemukan sekitar tanaman dalugha. Kecoa jenis ini di sebut juga sebagai kecoa penggali karena umumnya menggali tanah yang gembur, berhumus dan tumpukantumpukan sampah. Pada umumnya kecoa ini ditemukan di bawah tumpukan ranting, pelepah atau dedaunan yang busuk di tanah yang lembab.Kecoa jenis ini merupakan hama pada perkebunan daerah tropis yang memakan bagian-bagian tanaman termasuk tanaman dalugha (Gambar 31).

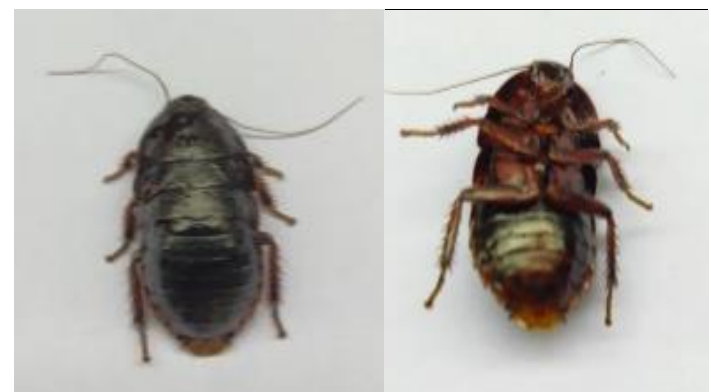

Gambar 31. Kecoa Surinam (Pycnoscelus surinamensis) pada hutan tanaman dalugha

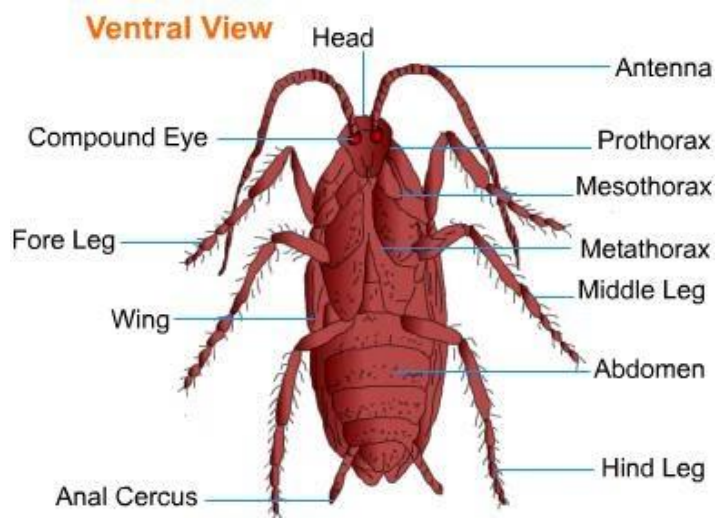

Gambar 32. Struktur tubuh kecoa Surinam (Pycnoscelus surinamensis)

Berdasarkan pengamatan morfologi tubuh kecoa Surinam pada Gambar 32, dapat diuraikan sebagai berikut: kecoa surinam memiliki tubuh berwarna coklat tua kehitaman dengan sayap yang mengkilap. Pada bagian pelindung kepala memiliki garis berwarna putih pucat. Nimfa kecoa jenis ini memiliki berwarna putih bening dengan rahang dan duri berwarna oranye sampai coklat dan bintik mata lebih gelap daripada bagian kepala lainnya. Nimfa yang lebih tua memiliki segmen perut anterior hitam mengkilat dan kasar sedangkan segmen posterior berwarna hitam kusam .

Berbeda dengan kecoa lainnya, kecoa surinam merupakan spesies yang unik karena dapat bereproduksi secara partenogenetik yakni suatu bentuk reproduksi aseksual di mana embrio berkembang dari telur yang tidak dibuahi. Diketahui bahwa $P$. surinamensis juga bertindak sebagai inang perantara cacing gelang parasit Oxyspirura mansoni dan Oxyspirura parvorum yang menginfeksi mata unggas dan dikenal sebagai cacing mata ayam. Berdasarkan karakter morfologi, identifikasi kecoa jenis ini termasuk dalam family Blaberidae, genus Pycnoscelus, dan tergolong dalam spesies Pycnoscelus surinamensis.

\section{Kelas Oligochaeta}

Karakter morfologi dan identifikasi jenis-jenis hama pada tanaman dalugha yang tergolong dalam kelas Oligochaeta ditemukan salah satu jenis cacing yang termasuk dalam dalam filum Annelida. Cacing jenis ini merupakan cacing tanah yang umumnya ditemukan hidup dalam tanah yang lembab dan basah. Pada hutan tanaman dalugha ditemukan cacing tanah setelah umbi tanaman dalugha dikeluarkan dari dalam tanah. Cacing tanah terlihat bergerak dengan menggunakan otot longitudinalnya (Gambar 33).

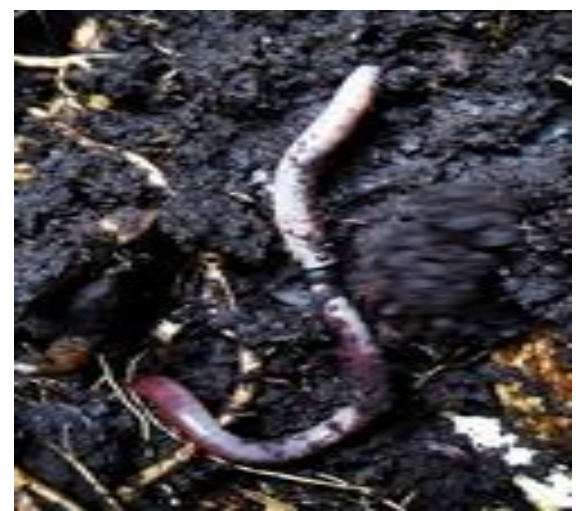

Gambar 33. Cacing Tanah (Lumbricus rubellus) ditemukan dalam tanah ketika umbi dalugha dikeluarkan ke atas permukaan tanah. 


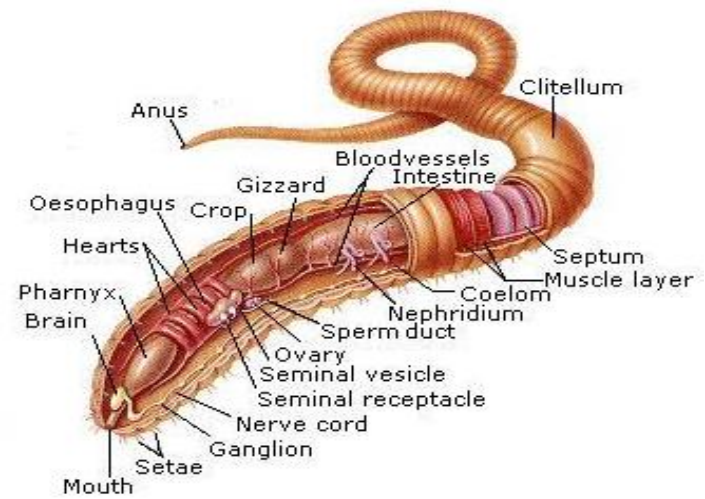

Gambar 34. Struktur tubuh cacing tanah (Lumbricus rubellus)

Menurut Gily et al. (2020) cacing tanah hidup di tanah di daerah tropis dan memiliki bentuk tubuh bilateral simetris ditutupi dengan kutikula tipis. Tubuh cacing tanah di bagian punggung berwarna merah jambu sampai merah tua dan berbentuk bulat sedangkan di bagian bawah atau ventral berwarna lebih muda dan berbentuk datar. Ada lendir di tubuh yang merupakan cairan diproduksi oleh kelenjar epidermis untuk melumasi tubuh, memfasilitasi pergerakan di dalam tanah, dan membantu pernapasan. Ukuran dari tubuh cacing tanah relatif kecil dengan panjang 4$7 \mathrm{~cm}$ dan memiliki 100 hingga 180 segmen, dan setiap segmen memiliki beberapa setae yang berfungsi sebagai pegangan di mana cacing tanah berada terletak.

Cacing ini tidak memiliki mata, dengan prostomium sebagai organ saraf sensorik, akan membuatnya lebih peka terhadap materi di sekitarnya. Pada cacing tanah, bagian pencernaan berada di dalam bentuk prostomium yang berbentuk seperti bibir, faring, kerongkongan, tembolok, otot perut, usus dan dubur. Sistem respirasi cacing tanah didukung oleh kulit sebagai alat pertukaran oksigen dan karbondioksida dan melewati pembuluh kapiler di seluruh kutikula jaringan pada lapisan atas kulit. Kutikula berfungsi untuk menjaga kelembapan dengan lendir yang diproduksi oleh epidermis. Oksigen yang ada dalam pembuluh darah kemudian didistribusikan ke seluruh bagian tubuh melalui peredaran darah. Cacing tanah memiliki organ reproduksi betina dan jantan dalam satu tubuh, tetapi hewan-hewan ini tidak dapat bereproduksi sendiri. Alat reproduksi betina memiliki sepasang ovarium dan sepasang infundibulum dan alat reproduksi jantan memiliki dua pasang testis. Berdasarkan karakter morfologi, cacing jenis ini tergolong dalam ordo Haplotaxida dan famili Lumbricidae. Hasil identifikasi cacing ini termasuk dalam genus Lumbricus dan spesies Lumbricus rubellus (Gambar 34).

\section{KESIMPULAN}

Karakter morfologi dan identifikasi keragaman hama pada tanaman dalugha di Kabupaten Kepulauan Talaud, Provinsi Sulawesi Utara dikelompokkan dalam tiga kelas yaitu kelas gastropoda antara lain: bekicot (Achatina fulica), keong semak (Bradybaena similaris), siput hijau (Rhinocochlis nasuta), siput pita (Caracolus marginella), siput kebun (Cornu aspersum), dan sumpil (Subulina octona), kelas insekta yaitu belalang hijau (Oxya servile), jangkrik semak (Tettigonia caudate), kumbang daun (Asphaera lustrans), kepik kaki daun tumbuhan (Leptoglossus australis), kutu kebul (Bemisia tabaci), semut kebun hitam (Lasius niger), ulat tanduk talas (Theretra oldenlandiae), kecoa (Periplaneta americana L.), dan kecoa Surinam (Pycnoscelus surinamensis) serta Kelas oligochaeta yaitu cacing tanah (Lumbricus rubellus).

\section{DAFTAR PUSTAKA}

Anonim, 2020a. Bekicot-Taksonomi, Morfologi, Jenis, Habitat, Keunikan, Makanan \& Reproduksi. https://rimbakita.com/bekicot/.

Anonim, 2020b. https://en.wikipedia.org/ wiki/Cornu_aspersum.

Anonim, 2020c. https://id.wikipedia.org/wiki /Sumpil.

Anonim, 2020d. https://jenis.net/belalanghijau/.

Anonim, 2020e. Lasius niger (black garden ant).https://www.antkeepers.com/antspecies/lasius-niger/. 
Auffenberg, K., Stange, Lionel, A., Capinera, J.L. \& White, J. 2011. Pleurodontid snails of Florida, Caracolus marginella (Gmelin), Zachrysia provisoria (L. Pfeiffer), Zachrysia trinitaria ( $L$. Pfeiffer),

(Gastropoda:Pleurodontidae).

Entomology and Nematology Department, Florida Cooperative Extension Service, Institute of Food and Agricultural Sciences, University of Florida.

Erniwati. 2012. Biologi jangkrik (Orthoptera: Gryllidae) budidaya dan peranannya. Fauna Indonesia, 11(2): 10 -14.

Evangelio, F. 1996. Cyrtosperma merkusii (PROSEA). Plant Resources of SouthEast Asia, 7: 61 (1857).

Gily, P., Gulo, Y., Lailani, D., Soraya, A., Wardhani, M., Nasution, F. \& Wahyuni, S. 2020. Analyze Effectiveness Extract of Worm Lumbricus Rubellus and Pheretima Based on Bacteria Salmonella Typhi and Staphylococcus Aureus. Department of Tropical Medicine, Faculty of Medicine, Universitas Prima Indonesia. International Journal of Scientific Engineering and Science, 4(2): 1-5.

Hine, R.S. \& Martin, E. 2005. Oxford Dictionary of Biology, $5^{\text {th }}$ ed. (R.S. Hine, \& E. Martin, Eds.) New Delhi: Oxford Univerity Pers.http:// edis.ipas.uf/.edu/pp104.http:/www.blue berries.msu.edu.pdf/E3039.pdf

Kay, Daisy. E., 1987. Crop and Product Digest. No. 2-Root Crops, Second Edition. London: Tropical Development and Research Institute, xv \& 380 pp. 127 Clerkenwell Road London EC1R 5DB.

Katsaruware-Chapoto, R.D., Mafongoya, P.L. \& Gubba, A. 2017. Responses of Insect Pests and Plant Diseases to Changing and Variable. Journal of Agricultural Science, 9(12).

Lintang, M., Layuk, P. \& Joseph, G.H. 2016. Karakteristik Tepung Umbi Daluga (Cyrtosperma merkussi), Wongkai (Dioscorea sp), Kolerea (Colocasia sp), dan. Jurnal Penelitian Pascapanen Pertanian, 13(2): 84-91.
Panhal, S. \& Ung, L.M. 2001. Rhinocochlis nasuta (metcalfe 1851), one of the world's most beautiful and rare land snails. Department of Biology, Faculty of Science, Chulalongkorn University, Bangkok 10330, Thailand. Sarawak Museum, 93566 Kuching, Sarawak, Malaysia. Walkerana, 2001, 12(28): 9596.

Raco, J.R. 2010. Metode Penelitian Kualitatif Jenis, Karakteristik, dan Keunggulannya. Penerbit PT Grasindo, Jakarta.

Rao, S. 2011. Salinity Tolerance of Giant Swamp Taro (Cyrtosperma merkusii); In vitro and In vivo. A thesis submitted in fulfilment of the requirements of the Degree of Master ofScience. School of Biological and Chemical Sciences. Faculty of Science, Technology and Environment. The University of the South Pacific

Ratag, S.P., Pangemanan, P.P. \& Mingkid, W.M. 2018. The Dalugha (Cyrtosperma Merkusii (Hassk) Schott) Adaptation to Open and Shaded Light Conditions on the Nitu Island, Tatoareng District, Sangihe Regency. International Journal of Science and Engineering Investigations, 7(79).

Ratnadass, A., Fernandes, P., Avelino, J. \& Habib, R. 2012. Plant species diversity for sustainable management of crop. Agron. Sustain. Dev, 32: 273-303.

Serniotti, E.N., Guzmán, L.B., Beltramino, A.A., Vogler, R.E., Rumi, A. \& Peso, J.G. 2019. New distributional records of the exotic land snail Bradybaena similaris (Férussac, 1822) (Gastropoda, Bradybaenidae) in Argentina. Instituto de Biología Subtropical, Consejo Nacional de Investigaciones Científicas y Técnicas - Universidad Nacional de Misiones, Rivadavia 2370, Posadas, Misiones, N3300LDX, Argentina, (8).

Shapovalov, V.B., Shapovalov, Y.B., Bilyk, Z.I., Megalinska A.P. \& Muzyka, I.O. 2020. The Google Lens analyzing quality: an analysis of the possibility to use in the educational process. National Center "Junior Academy of Sciences of Ukraine", 38/44, Dehtiarivska Str., Kyiv, 04119, Ukraine. Vol.2547 (09). 
Sugiyono. 2016. Metode Penelitian Kuantitatif, Kualitatif, dan Kombinasi (Mixed Methods). Alfabeta, Bandung.

Sujiono, S. 2015. Mengenal Serangga Hama Ubi Jalar. https://berita. bbpopt.id/2015 /03/hama-ubi/\#.

Sumarna, H. 2018. Pengendalian Hama dan Penyakit pada Tanaman Talas. http:// saketi123.blogspot. com /2018/07/ pengendalian-hama-dan-penyakitpada.html
Sutoyo. 2010. Keanekaragaman Hayati Indonesia. Buana Sains, 10(2): 101106.

Suyitno. 2018. Metode Penelitian Kualitatif: Konsep, Prinsip dan Operasionalnya. Akademia Pustaka, Tulungagung.

Tubby, K.V. \& Webber, J.F. 2010. Pests and diseases threatening urban trees under a changing climate. Forestry, 83(4): 451458. 